\title{
Effects of co-substrate on biogas production from cattle manure: a review
}

\author{
F. Tufaner' ${ }^{1}$ Y. Avşar ${ }^{2}$
}

Received: 20 August 2015/Revised: 24 May 2016/Accepted: 9 July 2016/Published online: 20 July 2016

(C) Islamic Azad University (IAU) 2016

\begin{abstract}
This literature review surveys the previous and current researches on the co-digestion of anaerobic processes and examines the synergies effect of co-digestion with cattle manure. Furthermore, this review also pays attention to different operational conditions like operating temperature, organic loading rate (OLR), hydraulic retention time (HRT), chemical oxygen demand (COD) and volatile solid (VS) removal efficiency and biogas or methane production. This review shows that anaerobic mono-digestion of cattle manure usually causing poor performance and stability. Anaerobic studies were generally performed under mesophilic conditions maintained between 35 and $37^{\circ} \mathrm{C}$. Organic waste loading rate generally ranges from 1 to $6 \mathrm{~g}$ VS-COD L ${ }^{-1}$ day $^{-1}$ stable condition in anaerobic digester. Generally, studies show that HRT for co-digestion of fruit-vegetables waste and industrial organic waste appears to exceed 20 days. However, the anaerobic co-digestion process is generally operated at HRT of between 10 and 20 days. VS and COD removal efficiency usually reaches up to $90 \%$ due to codigestion with different type organic waste. Methane-biogas production is generally obtained between 0.1 and 0.65 $\mathrm{L} \mathrm{CH}_{4}$-biogas $\mathrm{g}^{-1}$ VS.
\end{abstract}

F. Tufaner

ftufaner@adiyaman.edu.tr

1 Department of Environmental Engineering, Faculty of Engineering, Adiyaman University, 02040 Adiyaman, Turkey

2 Department of Environmental Engineering, Faculty of Civil Engineering, Y1ldız Technical University, 34220 Istanbul, Turkey
Keywords Cattle manure - Organic waste $\cdot$ Co-digestion . Anaerobic digestion $\cdot$ Biogas production

\section{Introduction}

Anaerobic co-digestion technology allows concurrent digestion of different solid and liquid wastes (Dias et al. 2014). Anaerobic treatment has been considered as the waste-to-energy technology and has been largely used in the digestion of different organic wastes, like animal manure, food waste, organic fraction of municipal solid waste and sewage sludge ( $\mathrm{Li}$ et al. 2009; Kavitha et al. 2015a).

The production of animal manure in large-scale farms has substantially expanded in the world (Gungor-Demirci and Demirer 2004). Livestock manure causes most environmental problems such as greenhouse gas, odor problems, airborne ammonia, high counts of fecal coliform bacteria and pathogens, rodents, insect, flies and other pests, release of animal pathogens, surface- and groundwater contamination, deterioration of biological structure of the earth and catastrophic spills (Nelson and Lamb 2002; Sakar et al. 2009; Sung and Santha 2003; Packyam et al. 2015).

Most livestock manure is generally produced by cattle in the world. Cattle manure is a complex type of substrate composed of carbohydrates, proteins and fats (McInerney 1998). During anaerobic digestion (AD) process, complex organic matter is hydrolyzed and fermented to short-chain fatty acids (such as acetic, propionic, butyric and smaller amounts of isobutyric, valeric, isovaleric acids), alcohols, $\mathrm{H}_{2}$ and $\mathrm{CO}_{2}$ (Ahring et al. 2001; Ozturk 2007; Sawyer et al. 2003). Acetic acid, $\mathrm{H}_{2}$ and $\mathrm{CO}_{2}$ are directly utilized by methanogenic phase. Other hydrolysis and acidogenesis 
products are transformed by acetogenic bacteria into $\mathrm{H}_{2}$, $\mathrm{CO}_{2}$ and acetic acid (Ozturk 2007).

Ruminants manure, especially cattle, is very helpful for beginning the fermentation phase, because it already has the necessary methanogenic bacteria. However, the fermentation of manure alone results in lower methane generation due to moderate anaerobic biodegradability of about 45-50\% (Rico et al. 2007). Moreover, the biogas production from cattle manure is lower than that obtained from other farm animals, since cattle manure contains leftover lignin complexes from fodder that are very resistant to AD (Monteiro et al. 2011). However, the high water content (70-90\%) and buffer capacity of manure have a positive effect on AD stability. Consequently, most of the farm-type anaerobic digesters are operated manure together with organic wastes (called co-digestion) (Rico et al. 2014).

The substrate-to-inoculum ratios between 2 and 6 (as VS) are typically used at the laboratory scale, and it is suggested that substrate-to-inoculum ratio really applied in industry can be optimized. By considering only the first days of operation, some studies showed an inefficiency of anaerobic digestion for substrate-to-inoculum ratio higher than 4 (Motte et al. 2013). At the same time, anaerobic digestion of microalgae has highest productivities at substrate-to-inoculum ratios of $1 / 2$ (Alzate et al. 2012).

Mixing substrates for co-digestion have many advantages including environmental, technology and economic benefits when contrasted with a single substrate processing (Brown and Li 2013). Over the last years, several authors investigated the effect on the performance of the AD process by simultaneously treating cattle manure as well as wastes containing high levels of organic matter or energy crops (Alvarez and Liden 2008; Comino et al. 2009; Lehtomaki et al. 2007; Nasir et al. 2012; Yangin-Gomec and Ozturk 2013). This co-digestion method, if co-substrate is used at the appropriate rate, can give interesting results because the synergistic impact indicated by different organic substrates when processed simultaneously (Angelidaki and Ellegaard 2003; Chen et al. 2010; Dias et al. 2014; El-Mashad et al. 2004; Hills and Roberts 1981; Lehtomaki et al. 2007; Li et al. 2009, 2011; Macias-Corral et al. 2008; Mata-Alvarez et al. 2000; Rao and Baral 2011; Umetsu et al. 2006). For optimal carbon-to-nitrogen ratio and $\mathrm{pH}$ diverse substrates are mixed for best biogas production (Khan and Martin 2016). One of the techniques for the economic sustainable of biogas systems is to improve their biogas production about $50 \%$ by co-digesting the
Fig. 1 Parametres of operating or performance compared to biogasmethane production; a temperature $\left(\mathrm{T}^{\circ} \mathrm{C}\right)$, b OLR $\left(\mathrm{g}\right.$ VS-COD L ${ }^{-1}$ $\mathrm{d}^{-1}$ ), c HRT (day), d VS-COD removal (\%)

animal manure with more degradable wastes containing high levels of organic matter as long as such organic wastes are reachable in the digester region (Xie et al. 2011; Khan and Martin 2015).

The benefits of co-digestion are evidently and clearly inexpensive, and to a simple technology and to remember ecological advantages, such as reduction in concentration toxic compounds, arranged demand of nutrients, synergistic effects of anaerobic bacteria, improved biodegradable substrate loading, increased in biogas production, hygienic stabilization and enhanced rate of digestion (Sosnowski et al. 2003), adjustment percent of moisture and $\mathrm{pH}$, supply of buffer capacity. All these benefits are very important for stability and performance of the anaerobic process (Esposito et al. 2012).

Organic-rich wastes and residues include a considerable amount of biodegradable organic carbon. The range of biogas generation from several biodegradable waste is stated as $0.20-1.11 \mathrm{~m}^{3} \mathrm{~kg}^{-1}$ of dry matters $\left(\mathrm{CH}_{4}\right.$ content of 57-69 \%); e.g., biogas yield per unit weight of dry matters is stated as $0.31 \mathrm{~m}^{3} \mathrm{~kg}^{-1}$ for the cattle manure (YanginGomec and Ozturk 2013).

The anaerobic biomethanization studies from digestion of cattle manure alone and co-digestion of fruit and vegetable wastes, organic household wastes, industrial organic wastes and sewage sludge wastes are reported in Fig. 1. The aim of this study is not only to review the previous and current researches on the co-digestion of anaerobic processes by various wastes containing high levels of organic matter, but also to indicate the synergies effect of co-digestion with cattle manure. Furthermore, this review also pays attention to different operational conditions like operating temperature, organic loading rate, hydraulic retention time, COD and volatile solid removal efficiency and biogas or methane production.

\section{Feedstocks for anaerobic digestion}

The most important premise of producing high-quality digestate is the utilization of high-quality feedstock for the digestion process. Some feedstocks are difficult or unsuitable for mono-digestion because of their unfavorable $\mathrm{C} / \mathrm{N}$ 


\section{Cattle manure alone \\ Co-digestion of fruit and \\ Co-digestion of Co-digestion of Co-digestion vegatable waste \\ organic household industrial organic \\ of sludge}
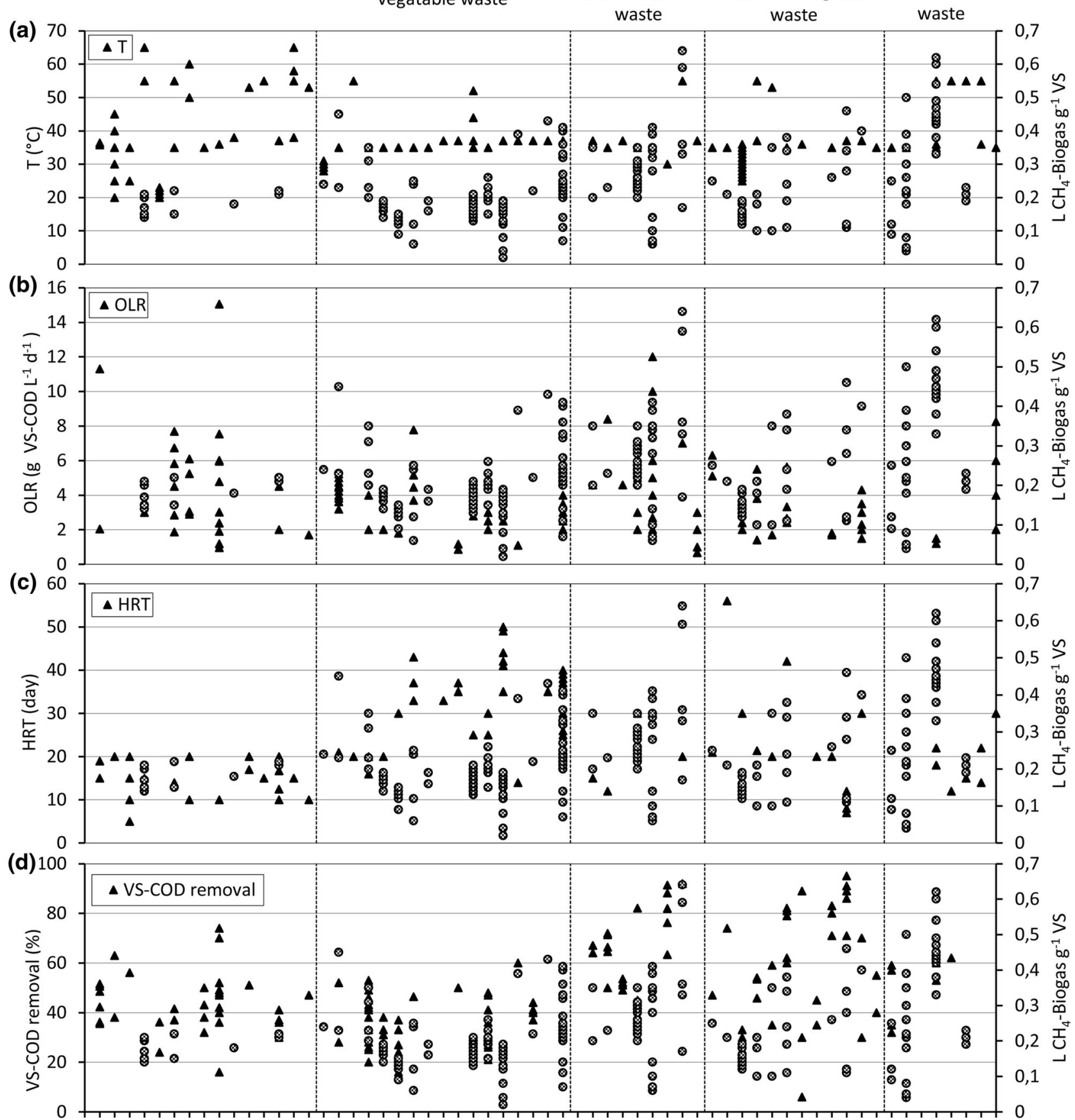

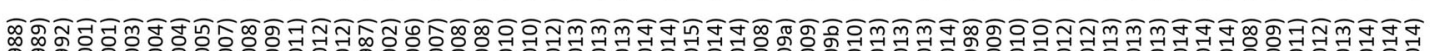

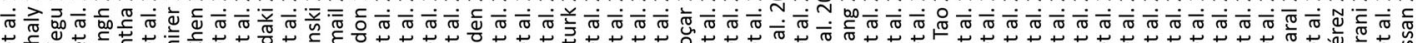

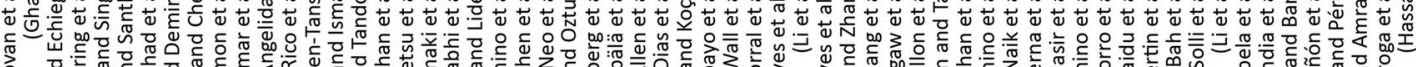

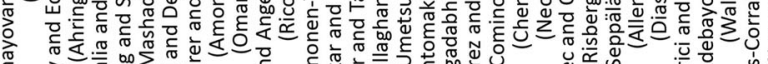

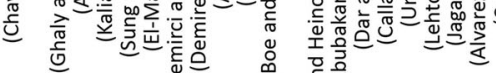
产

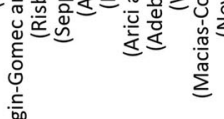

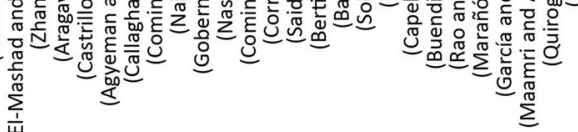


ratios or high lipid content. Under these circumstances, codigestion is the best approach to resolve any imbalance and improve volumetric methane productivity (Wellinger et al. 2013). In general, cattle manure biodegrades more slowly than other organic waste because of hay materials. The addition of co-digestion feedstocks can improve the biodegradability and the VS in the anaerobic reactor by including the co-digestion of cattle waste and the addition of food waste, fruit or vegetable waste, industrial organic waste or sewage sludge (Callaghan et al. 1998; Naik et al. 2010; Rao and Baral 2011; Zhang et al. 2013). The physical and chemical characteristics of the feedstocks have significant effect on the overall anaerobic phase for designing and operating anaerobic reactors because they affect biogas generation and digestion stability during anaerobic process. The production of biogas from any feedstocks is highly dependent on the $\mathrm{C} / \mathrm{N}$ ratio of the substrate, concentration, $\mathrm{pH}$ and temperature (Dioha et al. 2013). Nitrogen provides an essential element for synthesis of amino acids and is converted to ammonia which neutralizes the volatile acids produced by fermentative bacteria, thus providing suitable $\mathrm{pH}$ conditions for digestion. Also, the small amount of nitrogen causes nutrient limitation and ammonia toxicity occurs when nitrogen has too much levels in the substrate. The proper $\mathrm{C} / \mathrm{N}$ ratio for anaerobic digestion (AD) is between 20 and 35 (Abbasi et al. 2011; Ghasimi et al. 2009; Zhang and Zhang 1999). Cattle manure has low $\mathrm{C} / \mathrm{N}$ ratio of 11-14 the nutrients requirement for anaerobic bacteria (Hashimoto 1983; Hills and Roberts 1981). C/N ratios of cattle manure are observed between 5 and 26.5 (Bah et al. 2014; Chen et al. 2010; Corro et al. 2013; Dias et al. 2014; García and Pérez 2013; Lehtomaki et al. 2007; Li et al. 2009; Risberg et al. 2013; Solli et al. 2014).

The nutrients content of organic substrates determines the biogas quality and quantity. Maximum methane yield requires adequate and efficient nutrient supply for microorganisms in the digester (Amon et al. 2007). Macronutrients elements (C, H, N, O and S) must be present in the substrate for microbial growth to occur. More balanced macronutrients in anaerobic co-digestion process increased buffering capacity are sufficient to maintain a stable digestion situation (Chen et al. 2010). Significant parts of the $\mathrm{C}, \mathrm{H}$ and $\mathrm{O}$ are converted to $\mathrm{CH}_{4}$ and $\mathrm{CO}_{2}$, whereas any $\mathrm{N}$ and $\mathrm{S}$ that are not join into new biomass are rapidly reduced to ammonia and sulfides in either soluble or gaseous form. Both ammonia and sulfides are toxic to methanogens in a critical concentration (Wellinger et al. 2013). Ammonia toxicity occurs at concentration above
$2500 \mathrm{mg} \mathrm{L}^{-1}$ (Borja et al. 1996; Chen et al. 2008; Hashimoto 1986). If the concentration of soluble sulfides exceeds $50 \mathrm{mg} \mathrm{L}^{-1}$, the inhibition starts in anaerobic process (Imai et al. 1998; Koster et al. 1986; Lawrence and McCarty 1969; Speece 1983). The micronutrients (trace elements) such as $\mathrm{Ni}, \mathrm{Co}, \mathrm{Mo}, \mathrm{Fe}, \mathrm{Se}, \mathrm{Wo}, \mathrm{Zn}, \mathrm{Cu}$ and $\mathrm{Mn}$ are required for $\mathrm{AD}$ (Wellinger et al. 2013). The lack of the micronutrient requirement of methanogens failed many anaerobic digester (Khanal 2011). Manures provide a wide range of nutrients, while the addition of other organic wastes increases the methane yield of the process (Seppälä et al. 2013). Compared with cattle manure, the concentration of micronutrients was obviously fewer in food waste (Zhang et al. 2013; 2015), in plant-based material and waste (Demirel and Scherer 2011; Schattauer et al. 2011; Seppälä et al. 2013), higher in fresh leachate (Zhang et al. 2015), in sewage sludge (Ishaq et al. 2005).

\section{Important parameters for operating and performance}

The biogas generation highly depends on the temperature (Appels et al. 2011; Sanchez et al. 2001; Rani et al. 2012), but the HRT, OLR and substrate content in the feeding are also other significant operation parameters (Alvarez et al. 2006; Ashekuzzaman and Poulsen 2011; Khalid et al. 2011; Sakar et al. 2009; Kavitha et al. 2015b). The appropriate operation parameters of an anaerobic digestion related to the suitable factors are temperature, $\mathrm{pH}$, volatile fatty acids, alkalinity, $\mathrm{NH}_{3}-\mathrm{N}$, supplement of nutrients, trace elements, sulfides and heavy metals (Borja et al. 2006; Sakar et al. 2009; Yadanaparthi et al. 2014, Kavitha et al. 2015c). Hence, the stability parameters for a highly biogasification especially depend on temperature, HRT, OLR and substrate content in the feeding. For that reason, many authors have investigated about these parameters (Garcia-Pena et al. 2011; Wu et al. 2010). Furthermore, the most functional parameters for evaluating the efficiency of biogas production are the reduction in VS or COD (Debik and Coskun 2009; Demir et al. 2011; Demirer and Chen 2005; Razaviarani et al. 2013; Yangin-Gomec and Ozturk 2013; Ye et al. 2013). Figure 1 shows important parameters of operating or performance compared to biogas-methane production from different substrates.

Generally, most of the studies on AD of organic substrate have been experimented with one-stage mesophilic CSTR or semi-CSTR; informed sustainable and economic ways to enhance $\mathrm{CH}_{4}$-biogas production or to success 
higher VS-COD reduction are based on operation parameters.

During the period of time examined, some studies focused on comparing mesophilic and thermophilic conditions. The $\mathrm{CH}_{4}$-biogas production at thermophilic digestion was slightly higher than at mesophilic digestion. Thermophilic digestion is the most commonly used in particular cattle manure alone treatment. However, thermophilic digestion could not increase the biogas production and waste removal at a desired level. Also, the heating costs of thermophilic digestion are far higher. When we examine different temperature combinations of co-digestion in Fig. 1a, it is observed that more use of mesophilic conditions. The literature review shows that co-digestion of physical, chemical or biological pretreatments waste seems to be most suitable together with cattle manure in respect of their biogas production compared to raw waste. Pretreatments could result in reduced HRT, increased biogas yield, but most of the fruit-vegetables co-digestion study is generally operated higher than 20 days HRT. In order to provide essential nutrient balance in the waste mixture, codigesting macro- and micronutrients biodegradable rich substrate is beneficial for co-digestion. Organic loading rates were reported between 0.67 and $15.06 \mathrm{~g}$ VS-COD $\mathrm{L}^{-1}$ day $^{-1}$ and are shown in Fig. $1 \mathrm{~b}$. The higher biogas production of $0.7 \mathrm{~L} \mathrm{~g}^{-1} \mathrm{VS}$ removed is achieved by codigesting organic kitchen waste $(\mathrm{OKW})$ and cattle manure (OKW:CM mixing ratio 75:25) (Aragaw et al. 2013), but also cattle manure, food waste with glycerin $(87: 10: 3)$ (Castrillon et al. 2013) and cattle manure, food waste, sewage sludge (70:20:10 TS concentration around \%4) (Marañón et al. 2012) give very high methane generation of $0.64,0.61 \mathrm{~L} \mathrm{~g}^{-1}$ VS with $93 \%$ COD, $53 \%$ VS removal, respectively. In a field study, biogas yield of 0.41 and 0.47 $\mathrm{L} \mathrm{g}^{-1}$ VS loaded is conducted by co-digesting CM, chicken manure without or with maize silage around $50 \% \mathrm{VS}$ reduction in mesophilic condition (Yangin-Gomec and Ozturk 2013). The higher than $60 \%$ VS-COD reduction is often reported by co-digestion organic household waste and industrial organic waste (Bah et al. 2014; Bertin et al. 2013; Comino et al. 2012; Comino et al. 2009; Corro et al. 2013; Solli et al. 2014).

The performance data reveal that mesophilic condition of anaerobic process is more widely used compared to thermophilic condition because of higher system stability and low-cost operation managements. Nevertheless, thermophilic condition is used a lot of investigation in cattle manure alone study because of its more efficient to produce biogas at cattle manure digestion (Abubakar and Ismail 2012; Ahring et al. 2001; Boe and Angelidaki 2009; ElMashad et al. 2004; Mohaibes and Heinonen-Tanski 2012; Omar et al. 2008; Sung and Santha 2003). In cattle manure alone digestion studies, HRTs were conducted between 10 and 20 days, while biogas production usually ranged from 0.15 to $0.30 \mathrm{~L} \mathrm{CH}_{4} \mathrm{~g}^{-1} \mathrm{VS}$ day $^{-1}$ with COD-VS removal ranged from about 30-55 \% (Abbasi et al. 2011; Ahring et al. 2001; Demirer and Chen 2005; El-Mashad et al. 2004; Ghaly 1989; Gungor-Demirci and Demirer 2004; Omar et al. 2008; Rico et al. 2011; Sung and Santha 2003).

Anaerobic mono-digestion of cattle manure often caused poor performance and stability (Arici and Koçar 2015). The insufficiency of essential trace elements of organic waste is regarded as an important factor limiting anaerobic digestion. Anaerobic co-digestion of different kind of organic waste, especially cattle manure, allows for resolving any imbalance $(\mathrm{pH}$, alkalinity, macro- and micronutrients elements) and improving the biogas production with an effective bioreactor performance (Amon et al. 2007; Chen et al. 2010; Seppälä et al. 2013). Anaerobic co-digestion of cattle manure exhibits the synergies effect such as buffering capacities on inhibition of $\mathrm{pH}$ and ammonia, supplying trace elements and supporting necessary methanogenic bacteria (Hashimoto 1986; Macias-Corral et al. 2008; Rao and Baral 2011; Rico et al. 2007; Yangin-Gomec and Ozturk 2013).

According to the data shown in Fig. 1a, most of the anaerobic digestion was operated mesophilic condition with a temperature range from 35 to $37{ }^{\circ} \mathrm{C}$. According to the data presented in Fig. 1b, organic waste VS-COD loading rate generally ranges from 1 to $6 \mathrm{~g}$ VS-COD per liter of active reactor volume per day $\left(\mathrm{g}\right.$ VS-COD L ${ }^{-1}$ $\mathrm{day}^{-1}$ ) stable condition in anaerobic digester. However, suitable organic loading rate changes according to HRT and type-mixing ratio of waste. The study shows that HRT for co-digestion of fruit-vegetables waste and industrial organic waste appears to exceed 20 days in Fig. 1c. However, the anaerobic co-digestion process is generally operated at HRT of between 10 and 20 days. This review study shows that the anaerobic co-digestion could be operated at lower HRT and higher OLR together with higher biogas yield and better waste treatment (Fig. 1b, c) when organic waste such as cattle manure, household waste, industrial waste and sewage sludge, which are exposed to physical, biological and chemical pretreatment, are used for co-digestion. Chemicals addition for co-digestion is not needed, or very little addition is needed. 
The previous studies exhibited that up to $90 \%$ VS-COD removal was observed co-digestion of household and industrial organic wastes (Fig. 1d). Methane-biogas production was obtained between 0.1 and $0.65 \mathrm{~L} \mathrm{CH}_{4}$-biogas $\mathrm{g}^{-1}$ VS added. Furthermore, there seems to be a remarkable success of approximately $0.4 \mathrm{~L} \mathrm{CH}_{4}$-biogas $\mathrm{g}^{-1} \mathrm{VS}$ production in anaerobic co-digestion. Figure $1 \mathrm{~d}$ shows that where VS-COD reduction and $\mathrm{CH}_{4}$-biogas production from fruit-vegetables waste digestion are less when compared with household waste, industrial waste and sludge waste anaerobic digestion. Improving the operating parameters seems apparent in co-digestion process (Fig. 1a-d).

\section{Conclusion}

Anaerobic digestion of organic waste has been widely implemented in the waste stabilization process because of the need to be treated before being disposed in nature. Accordingly, several treatment processes have been developed. Due to the high organic matter content, anaerobic treatment technologies have been receiving significant attention for this type of waste. However, anaerobic digester which fed with monotype of substrates would not achieve waste reduction efficiency and production of biogas potential. Therefore, anaerobic co-digestion process has synergistic effects to increase biogas yield from the substrate and to decrease the volume of effluent waste because of suitable anaerobic process parameters with mixing waste. For this reason, many kinds of organic waste have been treated anaerobically in an appropriate way, such as fruit and vegetable waste, household organic waste, industrial organic waste, sewage sludge and livestock manure.

Most livestock manure was generally produced by cattle. Cattle manure is a complex type of substrate. Anaerobic mono-digestion of organic waste generally caused poor performance and stability. However, anaerobic co-digestion of different kind of organic waste, especially cattle manure, allows for resolving any imbalance and improving the biogas production with an effective bioreactor performance and anaerobic co-digestion of cattle manure exhibited the synergies effect. Treatment of waste in the anaerobic biodegradation depends on several conditions. The main conditions are related to reactor operating parameters such as temperature, OLR, HRT and feeding characteristics. Suitable intervals of parameters and their effects are very important on the anaerobic digestion and biogas production performance. However, unstable intervals of parameters can inhibit biodegradation process. Therefore, appropriate mixing strategies can help to solve these biodegradation process problems and to increase biogas production with treatment of waste.

Acknowledgments This research was conducted as part of an Adiyaman University (project number MÜFBAP2013-0001). The corresponding author would like to thank the Scientific and Technological Research Council of Turkey (TUBITAK) for the support by BIDEB-2211-C Domestic Ph.D. Scholarship Program Intended for Priority Areas. We also would like to express our gratitude to Prof. Dr. M. Talha Gönüllü for his valuable suggestions.

\section{References}

Abbasi T, Tauseef S, Abbasi SA (2011) Biogas energy, vol 2. Springer Science \& Business Media, New York

Abubakar B, Ismail N (2012) Anaerobic digestion of cow dung for biogas production ARPN. J Eng Appl Sci 7:169-172

Adebayo A, Jekayinfa S, Linke B (2014) Anaerobic co-digestion of cattle slurry with maize stalk at mesophilic temperature. Am J Eng Res 3:80-88

Agyeman FO, Tao WD (2014) Anaerobic co-digestion of food waste and dairy manure: effects of food waste particle size and organic loading rate. J Environ Manage 133:268-274. doi:10.1016/j. jenvman.2013.12.016

Ahring BK, Ibrahim AA, Mladenovska Z (2001) Effect of temperature increase from 55 to 65 degrees $\mathrm{c}$ on performance and microbial population dynamics of an anaerobic reactor treating cattle manure. Water Res 35:2446-2452

Allen E, Wall DM, Herrmann C, Murphy JD (2014) Investigation of the optimal percentage of green seaweed that may be co-digested with dairy slurry to produce gaseous biofuel. Bioresour Technol 170:436-444. doi:10.1016/j.biortech.2014.08.005

Alvarez R, Liden G (2008) Anaerobic co-digestion of aquatic flora and quinoa with manures from bolivian altiplano. Waste Manage 28:1933-1940. doi:10.1016/j.wasman.2007.11.002

Alvarez R, Villca S, Liden G (2006) Biogas production from llama and cow manure at high altitude. Biomass Bioenerg 30:66-75. doi:10.1016/j.biombioe.2005.10.001

Alzate ME, Muñoz R, Rogalla F, Fdz-Polanco F, Pérez-Elvira SI (2012) Biochemical methane potential of microalgae: influence of substrate to inoculum ratio, biomass concentration and pretreatment. Bioresour Technol 123:488-494

Amon T, Amon B, Kryvoruchko V, Zollitsch W, Mayer K, Gruber L (2007) Biogas production from maize and dairy cattle manureinfluence of biomass composition on the methane yield agriculture. Ecosyst Environ 118:173-182

Angelidaki I, Ellegaard L (2003) Codigestion of manure and organic wastes in centralized biogas plants-status and future trends. Appl Biochem Biotech 109:95-105. doi:10.1385/Abab:109:1-3: 95

Appels L, Lauwers J, Degrèvea J, Helsen L, Lievens B, Willems K, Impea JV, Dewil R (2011) Anaerobic digestion in global bioenergy production: potential and research challenges. Renew Sust Energ Rev 15:4295-4301. doi:10.1016/j.rser.2011.07.121 
Aragaw T, Andargie M, Gessesse A (2013) Co-digestion of cattle manure with organic kitchen waste to increase biogas production using rumen fluid as inoculums. Int J Phys Sci 8:443-450

Arici Ş, Koçar G (2015) The effect of adding maize silage as a cosubstrate for anaerobic animal manure digestion. Int $\mathrm{J}$ Green Energy 12:453-460

Ashekuzzaman SM, Poulsen TG (2011) Optimizing feed composition for improved methane yield during anaerobic digestion of cow manure based waste mixtures. Bioresour Technol 102:2213-2218. doi:10.1016/j.biortech.2010.09.118

Bah H, Zhang WQ, Wu SB, Qi DD, Kizito S, Dong RJ (2014) Evaluation of batch anaerobic co-digestion of palm pressed fiber and cattle manure under mesophilic conditions. Waste Manage 34:1984-1991. doi:10.1016/j.wasman.2014.07.015

Bertin L, Grilli S, Spagni A, Fava F (2013) Innovative two-stage anaerobic process for effective codigestion of cheese whey and cattle manure. Bioresour Technol 128:779-783. doi:10.1016/j. biortech.2012.10.118

Boe K, Angelidaki I (2009) Serial CSTR digester configuration for improving biogas production from manure. Water Res 43:166-172

Borja R, Sánchez E, Weiland P (1996) Influence of ammonia concentration on thermophilic anaerobic digestion of cattle manure in upflow anaerobic sludge blanket (UASB) reactors. Process Biochem 31:477-483

Borja R, Rincon B, Raposo F (2006) Anaerobic biodegradation of two-phase olive mill solid wastes and liquid effluents: kinetic studies and process performance. $\mathrm{J}$ Chem Technol Biot 81:1450-1462. doi:10.1002/Jctb. 1563

Brown D, Li Y (2013) Solid state anaerobic co-digestion of yard waste and food waste for biogas production. Bioresour Technol 127:275-280

Buendia IM, Fernandez FJ, Villasenor J, Rodriguez L (2009) Feasibility of anaerobic co-digestion as a treatment option of meat industry wastes. Bioresour Technol 100:1903-1909. doi:10.1016/j.biortech.2008.10.013

Callaghan FJ, Wase DAJ, Thayanithy K, Forster CF (1998) An examination of the continuous anaerobic co-digestion of cattle slurry and fish offal. Process Saf Environ 76:224-228. doi:10. 1205/095758298529524

Callaghan FJ, Wase DAJ, Thayanithy K, Forster CF (2002) Continuous co-digestion of cattle slurry with fruit and vegetable wastes and chicken manure. Biomass Bioenerg 22:71-77. doi:10.1016/ S0961-9534(01)00057-5

Capela I, Rodrigues A, Silva F, Nadais H, Arroja L (2008) Impact of industrial sludge and cattle manure on anaerobic digestion of the OFMSW under mesophilic conditions. Biomass Bioenerg 32:245-251. doi:10.1016/j.biombioe.2007.09.004

Castrillon L, Maranon E, Fernandez-Nava Y, Ormaechea P, Quiroga G (2013) Thermophilic co-digestion of cattle manure and food waste supplemented with crude glycerin in induced bed reactor (IBR). Bioresour Technol 136:73-77. doi:10.1016/j.biortech. 2013.02.076

Chayovan S, Gerrish JB, Eastman JA (1988) Biogas production from dairy manure-the effects of temperature perturbations. Biol Waste 25:1-16. doi:10.1016/0269-7483(88)90122-X

Chen Y, Cheng JJ, Creamer KS (2008) Inhibition of anaerobic digestion process: a review. Bioresour Technol 99:4044-4064. doi:10.1016/j.biortech.2007.01.057

Chen G, Zheng Z, Yang S, Fang C, Zou X, Zhang J (2010) Improving conversion of spartina alterniflora into biogas by co-digestion with cow feces. Fuel Process Technol 91:1416-1421
Comino E, Rosso M, Riggio V (2009) Development of a pilot scale anaerobic digester for biogas production from cow manure and whey mix. Bioresour Technol 100:5072-5078. doi:10.1016/j. biortech.2009.05.059

Comino E, Rosso M, Riggio V (2010) Investigation of increasing organic loading rate in the co-digestion of energy crops and cow manure mix. Bioresour Technol 101:3013-3019. doi:10.1016/j. biortech.2009.12.025

Comino E, Riggio VA, Rosso M (2012) Biogas production by anaerobic co-digestion of cattle slurry and cheese whey. Bioresour Technol 114:46-53. doi:10.1016/j.biortech.2012.02. 090

Corro G, Paniagua L, Pal U, Banuelos F, Rosas M (2013) Generation of biogas from coffee-pulp and cow-dung co-digestion: infrared studies of postcombustion emissions. Energy Convers Manage 74:471-481. doi:10.1016/j.enconman.2013.07.017

Dar GH, Tandon SM (1987) Biogas production from pretreated wheat straw, lantana residue, apple and peach leaf litter with cattle dung. Biol Waste 21:75-83

Debik E, Coskun T (2009) Use of the static granular bed reactor (SGBR) with anaerobic sludge to treat poultry slaughterhouse wastewater and kinetic modeling. Bioresour Technol 100:2777-2782. doi:10.1016/j.biortech.2008.12.058

Demir NM, Coşkun T, Debik E (2011) The effect of distinct operational conditions on organic material removal and biogas production in the anaerobic treatment of cattle manure. Paper presented at the world renewable energy congress, Linköpink, Sweden, 8-13 May 2011

Demirel B, Scherer P (2011) Trace element requirements of agricultural biogas digesters during biological conversion of renewable biomass to methane. Biomass Bioenerg 35:992-998. doi:10.1016/j.biombioe.2010.12.022

Demirer GN, Chen S (2005) Two-phase anaerobic digestion of unscreened dairy manure. Process Biochem 40:3542-3549. doi:10.1016/j.procbio.2005.03.062

Dias T, Fragoso R, Duarte E (2014) Anaerobic co-digestion of dairy cattle manure and pear waste. Bioresour Technol 164:420-423. doi:10.1016/j.biortech.2014.04.110

Dioha I, Ikeme C, Nafi'u T, Soba N, Yusuf M (2013) Effect of carbon to nitrogen ratio on biogas production. Int Res J Natl Sci 1:1-10

El-Mashad HM, Zhang RH (2010) Biogas production from codigestion of dairy manure and food waste. Bioresour Technol 101:4021-4028. doi:10.1016/j.biortech.2010.01.027

El-Mashad HM, Zeeman G, van Loon WKP, Bot GPA, Lettinga G (2004) Effect of temperature and temperature fluctuation on thermophilic anaerobic digestion of cattle manure. Bioresour Technol 95:191-201. doi:10.1016/j.biortech.2003.07.013

Esposito G, Frunzo L, Panico A, Pirozzi F (2012) Enhanced biomethane production from co-digestion of different organic wastes. Environ Technol 33:2733-2740. doi:10.1080/09593330. 2012.676077

García K, Pérez M (2013) Anaerobic co-digestion of cattle manure and sewage sludge: influence of composition and temperature international. J Environ Prot 3:8-15

Garcia-Pena EI, Parameswaran P, Kang DW, Canul-Chan M, Krajmalnik-Brown R (2011) Anaerobic digestion and co-digestion processes of vegetable and fruit residues: process and microbial ecology. Bioresour Technol 102:9447-9455. doi:10. 1016/j.biortech.2011.07.068

Ghaly A (1989) Biogas production from dairy manure using continuous mix and no-mix mesophilic reactors. Energy Sources $11: 221-235$ 
Ghaly A, Echiegu E (1992) Performance evaluation of a continuousflow no-mix anaerobic reactor operating on dairy manure. Energy Sources 14:113-134

Ghasimi S, Idris A, Chuah T, Tey B (2009) The effect of C: N: P ratio, volatile fatty acids and na levels on the performance of an anaerobic treatment of fresh leachate from municipal solid waste transfer station. Afr J Biotechnol 8:4572-4581

Goberna M, Schoen MA, Sperl D, Wett B, Insam H (2010) Mesophilic and thermophilic co-fermentation of cattle excreta and olive mill wastes in pilot anaerobic digesters. Biomass Bioenerg 34:340-346. doi:10.1016/j.biombioe.2009.11.005

Gungor-Demirci G, Demirer GN (2004) Effect of Initial COD concentration, nutrient addition, temperature and microbial acclimation on anaerobic treatability of broiler and cattle manure. Bioresour Technol 93:109-117. doi:10.1016/j.biortech.2003.10.019

Hashimoto AG (1983) Conversion of straw-manure mixtures to methane at mesophilic and thermophilic temperatures. Biotechnol Bioeng 25:185-200

Hashimoto AG (1986) Ammonia Inhibition of methanogenesis from cattle wastes. Agric Waste 17:241-261

Hassan R (2014) Anaerobic digestion of sewage sludge and cattle manure for biogas production: influence of co-digestion. Int Water Technol J 4:107-113

Hills DJ, Roberts DW (1981) Anaerobic-digestion of dairy manure and field crop residues. Agric Waste 3:179-189. doi:10.1016/ 0141-4607(81)90026-3

Imai T, Ukita M, Sekine M, Nakanishi H, Fukagawa M (1998) Treatment characteristics of high strength fermentation wastewater consisting of high sulfate and ammonia by UAHB process. Water Sci Technol 38:377-384

Ishaq F, Roussel J, Marquet CC, Bridgeman J (2005) Trace metal supplementation in sludge digesters. Paper presented at the AD 12 IWA World Congress, Guadalajara, Mexico

Jagadabhi P, Lehtomäki A, Rintala J (2008) Co-digestion of grass silage and cow manure in a CSTR by re-circulation of alkali treated solids of the digestate. Environ Technol 29:1085-1093

Kalia AK, Singh SP (2001) Effect of mixing digested slurry on the rate of biogas production from dairy manure in batch fermenter. Energy Sources 23:711-715

Kavitha S, Saranya T, Kaliappan S, Kumar SA, Yeom IT, Banu JR (2015a) Accelerating the sludge disintegration potential of a novel bacterial strain Planococcus jake 01 by $\mathrm{CaCl}_{2}$ induced deflocculation. Bioresour Technol 175:396-405

Kavitha S, Kannah RY, Yeom IT, Do K-U, Banu JR (2015b) Combined thermo-chemo-sonic disintegration of waste activated sludge for biogas production. Bioresour Technol 197:383-392

Kavitha S, Saranya T, Kaliappan S, Kumar SA, Yeom IT, Banu JR (2015c) Effect of $\mathrm{NaCl}$ induced floc disruption on biological disintegration of sludge for enhanced biogas production. Bioresour Technol 192:807-811

Khalid A, Arshad M, Anjum M, Mahmood T, Dawson L (2011) The anaerobic digestion of solid organic waste. Waste Manage 31:1737-1744. doi:10.1016/j.wasman.2011.03.021

Khan EU, Martin AR (2015) Optimization of hybrid renewable energy polygeneration system with membrane distillation for rural households in Bangladesh. Energy 93:1116-1127

Khan EU, Martin AR (2016) Review of biogas digester technology in rural Bangladesh. Renew Sustain Energy Rev 62:242-259. doi:10.1016/j.rser.2016.04.044
Khanal S (2011) Anaerobic biotechnology for bioenergy production: principles and applications. Wiley, Iowa

Koster I, Rinzema A, De Vegt A, Lettinga G (1986) Sulfide inhibition of the methanogenic activity of granular sludge at various $\mathrm{pH}-$ levels. Water Res 20:1561-1567

Lawrence AW, McCarty PL (1969) Kinetics of methane fermentation in anaerobic treatment. J Water Pollut Control Fed 41:R1R17

Lehtomaki A, Huttunen S, Rintala JA (2007) Laboratory investigations on co-digestion of energy crops and crop residues with cow manure for methane production: effect of crop to manure ratio. Resour Conserv Recy 51:591-609. doi:10.1016/j.resonrec.2006. 11.004

Li R, Chen S, Li X (2009) Anaerobic co-digestion of kitchen waste and cattle manure for methane production. Energ Source Part A 31:1848-1856. doi:10.1080/15567030802606038

Li J, Jha AK, He J, Ban Q, Chang S, Wang P (2011) Assessment of the effects of dry anaerobic co-digestion of cow dung with waste water sludge on biogas yield and biodegradability. Int J Phys Sci 6:3679-3688

Li J, Wei LY, Duan QW, Hu GQ, Zhang GZ (2014) Semi-continuous anaerobic co-digestion of dairy manure with three crop residues for biogas production. Bioresour Technol 156:307-313. doi:10. 1016/j.biortech.2014.01.064

Maamri S, Amrani M (2014) Biogas production from waste activated sludge using cattle dung inoculums: effect of total solid contents and kinetics study. Energy Procedia 50:352-359. doi:10.1016/j. egypro.2014.06.042

Macias-Corral M, Samani Z, Hanson A, Smith G, Funk P, Yu H, Longworth J (2008) Anaerobic digestion of municipal solid waste and agricultural waste and the effect of co-digestion with dairy cow manure. Bioresour Technol 99:8288-8293. doi:10. 1016/j.biortech.2008.03.057

Marañón E, Castrillon L, Quiroga G, Fernandez-Nava Y, Gomez L, Garcia MM (2012) Co-digestion of cattle manure with food waste and sludge to increase biogas production. Waste Manage 32:1821-1825. doi:10.1016/j.wasman.2012.05.033

Mata-Alvarez J, Mace S, Llabres P (2000) Anaerobic digestion of organic solid wastes. An overview of research achievements and perspectives. Bioresour Technol 74:3-16. doi:10.1016/S09608524(00)00023-7

McInerney MJ (1998) Anaerobic hydrolysis and fermentation of fats and proteins. In: Zehnder AJB (ed) Biology of anaerobic microorganisms. Wiley, New York

Mohaibes M, Heinonen-Tanski H (2012) Effect of temperature on survival of micro-organisms and performance of anaerobic twostage reactors treating cattle slurry. Environ Technol 33:573-578. doi:10.1080/09593330.2011.586056

Monteiro E, Mantha V, Rouboa A (2011) Prospective application of farm cattle manure for bioenergy production in Portugal. Renew Energ 36:627-631. doi:10.1016/j.renene.2010.08.035

Motte JC, Escudié R, Bernet N, Delgenes JP, Steyer JP, Dumas C (2013) Dynamic effect of total solid content, low substrate/ inoculum ratio and particle size on solid-state anaerobic digestion. Bioresour Technol 144:141-148

Naik S, Goud VV, Rout PK, Jacobson K, Dalai AK (2010) Characterization of Canadian biomass for alternative renewable biofuel. Renew Energ 35:1624-1631. doi:10.1016/j.renene.2009. 08.033 
Nasir IM, Ghazi TIM, Omar R, Idris A (2012) Palm oil mill effluent as an additive with cattle manure in biogas production. Procedia Eng 50:904-912. doi:10.1016/j.proeng.2012.10.098

Nelson C, Lamb J (2002) Haubenschild farms anaerobic digester, updated! The Minnesota Project

Neo S, Vintilă T, Bura M (2012) Conversion of agricultural wastes to biogas using as inoculum cattle manure and activated sludge. Sci Pap Anim Sci Biotechnol 45:328-334

Neves L, Oliveira R, Alves MM (2009a) Co-digestion of cow manure, food waste and intermittent input of fat. Bioresour Technol 100:1957-1962. doi:10.1016/j.biortech.2008.10.030

Neves L, Oliveira R, Alves MM (2009b) Fate of LCFA in the codigestion of cow manure, food waste and discontinuous addition of oil. Water Res 43:5142-5150. doi:10.1016/j.watres.2009.08. 013

Omar R, Harun RM, Mohd Ghazi T, Wan Azlina W, Idris A, Yunus R (2008) Anaerobic treatment of cattle manure for biogas production. In: Proceedings Philadelphia, annual meeting of American institute of chemical engineers, Philadelphia. pp 1-10

Ozturk I (2007) Anaerobic treatment and applications. Water Foundation Press, Istanbul

Packyam GS, Kavitha S, Kumar SA, Kaliappan S, Yeom IT, Banu JR (2015) Effect of sonically induced deflocculation on the efficiency of ozone mediated partial sludge disintegration for improved production of biogas. Ultrason Sonochem 26:241-248

Quiroga G, Castrillon L, Fernandez-Nava Y, Maranon E, Negral L, Rodriguez-Iglesias J, Ormaechea P (2014) Effect of ultrasound pre-treatment in the anaerobic co-digestion of cattle manure with food waste and sludge. Bioresour Technol 154:74-79. doi:10. 1016/j.biortech.2013.11.096

Rani RU, Kumar SA, Kaliappan S, Yeom IT, Banu JR (2012) Low temperature thermo-chemical pretreatment of dairy waste activated sludge for anaerobic digestion process. Bioresour Technol 103:415-424

Rao PV, Baral SS (2011) Experimental design of mixture for the anaerobic co-digestion of sewage sludge. Chem Eng $\mathrm{J}$ 172:977-986. doi:10.1016/j.cej.2011.07.010

Razaviarani V, Buchanan ID, Malik S, Katalambula H (2013) Pilotscale anaerobic co-digestion of municipal wastewater sludge with restaurant grease trap waste. J Environ Manage 123:26-33. doi:10.1016/j.jenvman.2013.03.021

Rico JL, Garcia H, Rico C, Tejero I (2007) Characterisation of solid and liquid fractions of dairy manure with regard to their component distribution and methane production. Bioresour Technol 98:971-979. doi:10.1016/j.biortech.2006.04.032

Rico C, Rico JL, Tejero I, Munoz N, Gomez B (2011) Anaerobic digestion of the liquid fraction of dairy manure in pilot plant for biogas production: residual methane yield of digestate. Waste Manage 31:2167-2173. doi:10.1016/j.wasman.2011.04.018

Rico C, Diego R, Valcarce A, Rico JL (2014) Biogas production from various typical organic wastes generated in the region of cantabria (Spain): methane yields and co-digestion tests. Smart Grid Renew Energy 5:128

Risberg K, Sun L, Leven L, Horn SJ, Schnurer A (2013) Biogas production from wheat straw and manure-impact of pretreatment and process operating parameters. Bioresour Technol 149:232-237. doi:10.1016/j.biortech.2013.09.054

Saidu M, Yuzir A, Salim MR, Azman S, Abdullah N (2013) Influence of palm oil mill effluent as inoculum on anaerobic digestion of cattle manure for biogas production. Bioresour Technol 141:174-176. doi:10.1016/j.biortech.2013.03.111
Sakar S, Yetilmezsoy K, Kocak E (2009) Anaerobic digestion technology in poultry and livestock waste treatment: a literature review. Waste Manage Res 27:3-18. doi:10.1177/0734242x07079060

Sanchez E, Borja R, Weiland P, Travieso L, Martin A (2001) Effect of substrate concentration and temperature on the anaerobic digestion of piggery waste in a tropical climate. Process Biochem 37:483-489. doi:10.1016/S0032-9592(01)00240-0

Sawyer CN, McCarty PL, Parkin GF (2003) Chemistry for environmental engineering and science. The Mcgraw-Hill series in civil and environmental engineering, 5th edn. McGraw-Hill, Boston

Schattauer A, Abdoun E, Weiland P, Plochl M, Heiermann M (2011) Abundance of trace elements in demonstration biogas plants. Biosyst Eng 108:57-65. doi:10.1016/j.biosystemseng.2010.10. 010

Seppälä M, Pyykkonen V, Vaisanen A, Rintala J (2013) Biomethane production from maize and liquid cow manure-effect of share of maize, post-methanation potential and digestate characteristics. Fuel 107:209-216. doi:10.1016/j.fuel.2012.12.069

Solli L, Bergersen O, Sorheim R, Briseid T (2014) Effects of a gradually increased load of fish waste silage in co-digestion with cow manure on methane production. Waste Manage 34:1553-1559. doi:10.1016/j.wasman.2014.04.011

Sosnowski P, Wieczorek A, Ledakowicz S (2003) Anaerobic codigestion of sewage sludge and organic fraction of municipal solid wastes. Adv Environ Res 7:609-616. doi:10.1016/S10930191(02)00049-7

Speece RE (1983) Anaerobic biotechnology for industrial wastewater treatment. Environ Sci Technol 17:416-427

Sung SW, Santha H (2003) Performance of temperature-phased anaerobic digestion (TPAD) system treating dairy cattle wastes. Water Res 37:1628-1636. doi:10.1016/S0043-1354(02)00498-0

Umetsu K, et al (2006) Anaerobic co-digestion of dairy manure and sugar beets. In: International congress series. Elsevier, Amsterdam, pp 307-310

Wall DM, Allen E, Straccialini B, O’Kiely P, Murphy JD (2014) Optimisation of digester performance with increasing organic loading rate for mono- and co-digestion of grass silage and dairy slurry. Bioresour Technol 173:422-428. doi:10.1016/j.biortech. 2014.09.126

Wellinger A, Murphy JD, Baxter D (2013) The biogas handbook: science, production and applications. Elsevier, Cambridge

Wu XM, Yang HH, Guo LJ (2010) Effect of operation parameters on anaerobic fermentation using cow dung as a source of microorganisms. Int $\mathrm{J}$ Hydrogen Energ 35:46-51. doi:10.1016/j. ijhydene.2009.10.039

Xie S, Lawlorb PG, Frostc ZH, Zhana X (2011) Effect of pig manure to grass silage ratio on methane production in batch anaerobic co-digestion of concentrated pig manure and grass silage. Biores Technol 102:5728-5733

Yadanaparthi SKR, Chen L, Glaze B (2014) Anaerobic co-digestion of dairy manure with potato waste. In: Idaho nutrient management conference, Idaho, ABD

Yangin-Gomec C, Ozturk I (2013) Effect of maize silage addition on biomethane recovery from mesophilic co-digestion of chicken and cattle manure to suppress ammonia inhibition. Energ Convers Manage 71:92-100. doi:10.1016/j.enconman.2013.03. 020

Ye JQ, Li D, Sun YM, Wang GH, Yuan ZH, Zhen F, Wang Y (2013) Improved biogas production from rice straw by co-digestion with kitchen waste and pig manure. Waste Manage 33:2653-2658. doi:10.1016/j.wasman.2013.05.014 
Zhang R, Zhang Z (1999) Biogasification of rice straw with an anaerobic-phased solids digester system. Bioresour Technol 68:235-245

Zhang CS, Xiao G, Peng LY, Su HJ, Tan TW (2013) The anaerobic co-digestion of food waste and cattle manure. Bioresour Technol 129:170-176. doi:10.1016/j.biortech.2012.10.138
Zhang WL, Zhang L, Li AM (2015) Anaerobic co-digestion of food waste with MSW incineration plant fresh leachate: process performance and synergistic effects. Chem Eng J 259:795-805. doi:10.1016/j.cej.2014.08.039 